\title{
Kemungkinan Penerapan Konsep Sistem Seting Dalam Penemukenalan Penataan Ruang Kawasan
}

nfn. Haryadi

Keywords: spatial, system, area, site, archaeology, theory

How to Cite:

Haryadi, nfn. Kemungkinan Penerapan Konsep Sistem Seting Dalam Penemukenalan Penataan Ruang Kawasan. Berkala Arkeologi, 15(3), 5-9. https://doi.org/10.30883/jba.v15i3.664

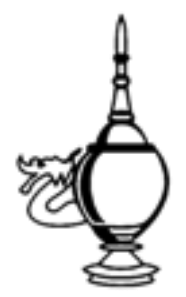

\section{Berkala Arkeologi}

https://berkalaarkeologi.kemdikbud.go.id/

Volume 15 No. 3, 1995, 5-9

DOI: $10.30883 /$ jba.v15i3.664

This work is licensed under a Creative Commons Attribution-NonCommercialShareAlike 4.0 International License. 


\title{
KEMUNGKINAN PENERAPAN KONSEP SISTEM SETING DALAM PENEMUKENALAN PENATAAN RUANG KAWASAN
}

\author{
Haryadi*
}

\section{Latar Belakang}

Berkembangnya kegiatan penelitian arkeologi dari dimensi bentuk ke dimensi ruang membutuhkan dukungan teori-teori ataupun konsepkonsep yang berkaitan dengan ruang. Salah satu kegiatan di bidang arkeologi yang perlu mendapatkan dukungan teori atau konsep ruang tersebut adalah kegiatan pelestarian sumber daya arkeologi dalam skala kawasan.

Konsep sistem seting yang berasal dari bidang ilmu arsitektur mempunyai kemungkinan untuk dimanfaatkan dalam menelaah kawasan ditinjau dari segi kegiatan manusia. Kegiatan dalam kawasan sangat bervariasi. Sebagai contoh, kawasan permukiman adalah batas ruang kegiatan bermukim. Kawasan perdagangan adalah batas ruang kegiatan perdagangan. Dalam konsep ini, kawasan didefinisikan sebagai batas wilayah dari sekelompok ruang-ruang atau setingseting tempat manusia melakukan kegiatannya. Sekelompok seting-seting tersebut tersusun dalam satu sistem yang mewadahi sistem kegiatan manusia, yang secara singkat disebut sistem seting

Kegiatan manusia disamping membutuhkan ruang atau seting bagi terselenggaranya kegiatan tersebut, juga membutuhkan peralatan untuk melakukan kegiatan tadi. Maka dari itu, da-lam sistem seting terdapat pula berbagai pera-latan bagi terselenggaranya kegiatan manusia. Ruang atau seting kegiatan beserta peralatan yang ada dalam ruang tersebut merupakan tan-da-tanda spasial dan fisik (spatial and physical traces) yang ada dalam kawasan. Dalam kondisi pada waktu kegiatan manusla sudah lama tidak ada lagi di kawasan, ruang dan tanda-tanda fisik tersebut secara utuh atau sebagian masih ada di sana. Dengan melestarikan dan menelusuri peninggalan verupa ruang dan peralatan akan dapat diketahui kegiatan manusia yang sudah lama tidak ada lagi.

Tujuan dari penulisan makalah ini adalah untuk membahas kemungkinan sumbangan konsep sistem seting dalam menunjang usaha pelestarian sumber daya arkeologis dalam kawasan. Keberhasilan pelestarian tersebut akan mem- bantu usaha mengetahui latar belakang budaya dan kegiatan manusia di dalam suatu kawasan

\section{Kawasan Dalam Konteks Skala Ruang}

Ruang dapat dikelompokkan dalam tiga kategori skala yang berbeda yaitu skala mikro, meso dan rnakro. Contoh ruang dengan skala mikro (disingkat: ruang mikro) adalah ruang-ruang dalam rumah tinggal atau bangunan seperti gu-dang, dapur, ruang tidur, kandang ternak dan ha-laman. Contoh ruang meso dapat berupa daerah permukiman seperti kampung, desa, ataupun area dengan batas adminstrasi seperti padukuh-an. RT, RW dan kalurahan. Ruang makro mempunyai luasan yang paling besar dan dapat terdiri dari beberapa ruang meso. Contohnya adaiah bagian dari kota seperti kawasan kota lama, kawasan perdagangan, kawasan budaya dan kawasan pariwisata. Disamping itu, ruang makro dapat juga berupa hamparan ekosistem alami seperti daerah pegunungan, daerah aliran sungai dan daerah pantai.

Baik ruang mikro, meso maupun makro terdiri dari komponen-komponen atau sub-sub ruang yang skalanya lebih kecil. Sebagai contoh, rumah yang termasuk dalam skala mikro terdiri dari komponen-komponen ruang tidur, ruang bersama, dapur, gudang, kandang dan halaman. Kampung yang berskala meso antara lain terdiri dari ruang berskala mikro seperti ruang terbuka, rumah-rumah, jalan kampung, ruang pertemuan dan ruang bermain. Ruang makro seperti kawasan perdagangan dapat terdiri dari ruang-ruang meso seperti area perbelanjaan, area kantor-kantor dan area parkir.

\section{Sistem Kegiatan Dan Sistem Seting}

Kegiatan didefinisikan sebagai hal yang dilakukan oleh makhluk hidup pada waktu tertentu (Bechtel and Zeisel, 1987). Kegiatan dapat mengarahkan pertanyaan tentang siapa, melakukan apa, dengan siapa, di mana dan kapan. Setiap kegiatan terdiri dari hubungan antara sub-sub kegiatan yang membentuk unit sistem kegiatan (Rapoport, 1977; 1986) (lihat diagram 1).Sebagaı

\footnotetext{
- Dosen Jurusan Teknik Arsitektur FT-UGM dan Kepala Pusat Penelitian Lingkungan Hidup Universitas Gadjah Mada (PPLH-UGM)
} 
contoh, kegiatan memasak terdiri dari sub kegiatan mencuci bahan mentah, memotong, menggoreng dan menyimpannya. Dalam setiap unit sistem kegiatan terkandung cara-cara tertentu dalam melakukan kegiatan dan aspek simbolis atau makna dari suatu kegiatan. Yang pertama adalah aspek manifes sedang yang kedua adalah aspek laten dari suatu kegiatan.

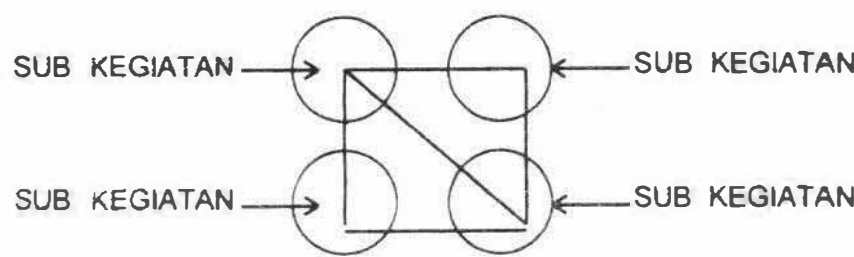

\section{DIAGRAM 1. SISTEM KEGIATAN MANUSIA}

Aspek manifes mudah ditemukenali sebab dapat dilihat sedang aspek laten sukar dikenal karena tidak terlihat nyata. Sebagai contoh, memanfaatkan dapur sebagai status simbol (contoh: menempatkan lemari es meskipun tidak ada listrik) lebih sukar untuk ditemukenali dibanding memanfaatkannya sekedar sebagai tempat untuk memasak makanan. Meskipun menyulitkan, aspek laten dari kegiatan perlu ditinjau bersama dengan aspek manifesnya.

Setiap komponen ruang merupakan wadah atau seting kegiatan tertentu dari manusia. Sebagai contoh dapur adalah wadah atau seting untuk kegiatan memasak, kandang untuk menjaga dan memelihara ternak sedang halaman untuk menanam jenis tumbuhan tertentu. Komponen-komponen ruang yang berfungsi sebaga seting kegiatan manusia saling berkait sesuai dengan keterkaitan jenisjenis kegiatan manusia. Kalau keterkaitan jenis-lenis kegiatan manusia disebut sistern kegiatan manusia, maka keterkaitan komponen-komponen ruang atau seting kegiatan manusia disebut sistem seting (lihat diagram 2).

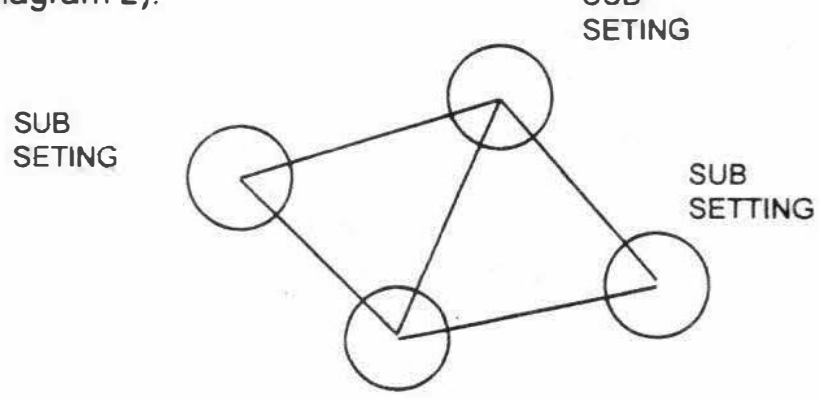

\section{DIAGRAM 2: SETING KEGIATAN DALAM} SISTEM (SISTEM SETING)

\section{Tanda-tanda Fisik Bagian Dari Sistem Seting Dalam Kawasan}

Selain membutuhkan ruang, kegiatan manusia juga membutuhkan peralatan untuk mela- kukan kegiatan tersebut. Untuk memasak perlu tungku pemanas, periuk, wajan dan sebagainya. Untuk tidur perlu amben atau tikar sedang untuk menanam di halaman perlu cangkul. Baik ruang ataupun alat-alat tersebut merupakan jejak atau tanda-tanda (traces) yang berupa spasial dan fisik (spatial and physical traces) yang dapat dipakai sebagai petunjuk untuk menelusuri kegiatan manusia dalam ruang. Dalam menunjang usaha untuk melestarikan kawasan lama yang pernah menjadi wadah kegiatan manusia, maka penelusuran melalui tanda-tanda spasial dan fisik akan dapat membantu usaha tadi. Baik tandatanda spasial maupun fisik akan dapat menggambarkan jenis-jenis ruang dan karakter kegiatan manusia pada waktu itu.

\section{Kontribusi Konsep Sistem Seting Dalam Penemukenalan Kawasan Konservasi.}

Konsep sistem seting adalah alat untuk menemukenali ruang-ruang yang merupakan wadah kegiatan manusia. Dalam kondisi dimana manusia sebagai pelaku kegiatan sudah tidak ada lagi, maka tanda-tanda yang berupa spasial maupun fisik akan dapat mengganti ketidak. hadiran manusia. Tanda-tanda tersebut akan dapat memberikan gambaran tentang ruang yang dimanfaatkan oleh manusia dalam melakukan kegiatannya, baik itu kegiatan sehari-hari, mingguan, bulanan, tahunan ataupun kegiatan yang bersifat sesaat, yang tidak ajeg.

Penyebaran atau distribusi tanda-tanda spasial dan fisik di dalam suatu kawasan bukanlah tidak beraturan. Mereka merupakan komponen-komponen dari sistem yang mempunyai kaidah-kaidah tertentu dalam susunannya. Kaitan dalam sistem inilah yang perlu diketahui teru-tama dalam usaha pelestarian suatu kawasan. Kalau usaha pelestarian kawasan hanya sekedar melestarikan sebagian dari sistem tersebut dan menghilangkan atau mengabaikan komponen yang lain, nilai pelestarian tersebut akan menjadı berkurang bahkan ada kemungkinan tidak mempunyai makna lagi kecuali untuk konsumsi tertentu. Apalagi kalau yang dihilangkan tersebut sebetulnya merupakan inti dari sistem tadi. Disinilah arti pentingnya sumbangan konsep sistem seting dalam menunjang pelestarian kawasan.

\section{Metoda Physical Traces (Metoda Penemukenal-an Tanda-tanda Spasial Dan Fisik)}

Jika konsep sistem seting menjelaskan keterkaitan wadah kegiatan manusia dalam ruang. maka metoda physical iraces adalah cara-cara untuk menemukenali keterkaitan wadah kegiatan tersebut melalui penelusuran tanda-tanda fisik 
maupun spasial tanpa kehadiran manusianya. Metoda untuk menemukenali penatean ruang kawasan melalui penelusuran benda-benda peninggalan (physical traces) pada dasamya merupakan kelengkapan konsep sistem seting.

Metoda penelusuran tanda-tanda fisik dan spasial memungkinkan peneliti untuk merekonstruksi kegiatan manusia dan seting atau wadah kegiatan tersebut. Peneliti bertindak seperti seorang detektif yang dengan bukti-bukti berupa benda-benda yang tertinggal di tempat kejadian akan dapat merekonstruksi kegiatan yang terjadi.

Contoh yang berupa penataan ruang rumah tradisional di bawah ini dapat ditelusuri melalui tanda-tanda spasial dan fisik berupa gubahan masa bangunan dan keausan tanah akibat tapaktapak kaki, Kesemuanya ini akan dapat menjelaskan arti dari bangurian yang ada di tengah-tengah (diagram 3)

Bangunan di tengah yang dikelilingi oleh bangunan-bangunan lain dalam bentuk lingkaran ternyata adalah tempat tinggal ibu. Di tempat ini ibu merupakan figur yang paling berperan dalam kehidupan keluarga. Kedudukannya paling sentral di antara anggota keluarga lainnya dan tercermin pada iokasi tempat kediamannya yang terletak di tengah-tengah bangunan-bangunan lain. Selain itu keausan tanah yang berbentuk radial dan menghubungkan tempat ibu dengan bangunan-bangunan lain disekelilingnya memberikan gambaran tentang kedudukan sentral dari si ibu tadi. RUMAHIBU

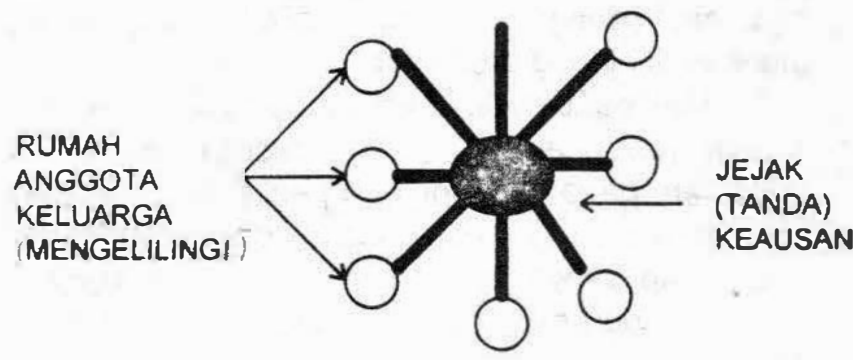

\section{DIAGRAM 3 : HUBUNGAN ANTAR SETING}

Baik bangunan tempat tinggal ibu yang terletak di tengah maupun tempat tinggal anggota keluarga lain yang mengelilinginya merupakan contoh tanda-tanda fisik maupun spasial yang keterkaitannya mempunyai arti tertentu. Demikian juga dengan adanya keausan tanah yang menghubungkan bangunan-bangunan tersebut. Semuanya akan memberikan gambaran tentang kegiatan manusia yang ada di situ meskipun manusianya sendiri tidak hadir. Peneliti diharapkan dapat merekonstruksi kejadian dari tanda-tanda fisik dan spatial tersebut tanpa kehadiran penghuni rumah tersebut.
Hal yang sama dapat dilakukan pada tanda-tanda fisik maupun spasial dalam skala yang lebih luas, baik skala meso maupun makro seperti skala kawasan. Dalam skala yang lebih luas, maka seharusnya tanda-tanda fisik dan spasial menjadi lebih kompleks. Kegiatan manu-sia juga akan rnenjadi lebih majemuk. Dengan sendirinya interpretasi melalui tanda-tanda fisik maupun spasial menjadi lebih sulit atau memer-lukan waktu lebih lama. Lebih-lebih jika tanda-tanda yang ada tidak lengkap lagi seperti dalam kasus peninggalan lama yang mengalami keru-sakan cukup parah.

Dalam kondisi serba tidak lengkap tadi, ada kalanya studi kepustakaan akan dapat membantu. Dokumen atau arsip lama sering menggambarkan sistem seting kegiatan manusia dalam suatu kawasan serta dilengkapi dengan ceritera tentang kegiatan yang terjadi di kawasan tadi. Dengan tersedianya dokumen tersebut, pekerjaan pelestarian kawasan akan lebih diperrnudah. Metoda physical traces yang dikombinasi dengan metoda studi kepustakaan akan dapat lebih memberikan hasil guna bagi kegiatan pelestarian kawasan.

\section{Beberapa Contoh Kemungkinan Penerapan Konsep Sistem Seting Dalam Pelestarian Kawasan}

Haryadi (1989), dalam disertasinya menggambarkan sistem seting sekelompok penduduk kampung Ratmakan Yogyakarta yang menghubungkan rumah mereka dengan seting-seting lain diluarnya. Hubungan antar seting tersebut terbentuk sebagai jawaban terhadap tekanan ekonomi yang mereka hadapi karena hidup di kota.

Untuk mengatasi tekanan ekonomi, penduduk kampung melakukan kegiatan ekonomi informal dengan memanfaatkan trotoir di beberapa tempat sepanjang jalan-jalan utama di sekitar kampung untuk menjajakan barang dagangannya. Jalan yang menjadi seting kegiatan mereka untuk berjualan makanan kecil, menjajakan rokok atau bekerja sebagai tukang parkir antara lain adalah jalan Suryotomo dan Malioboro. Disamping itu penduduk juga memanfaatkan pasar Beringharjo (sebelum pernugaran) dan pasar Sriwedani ( sebelum dibongkar) sebagai seting-seting lain untuk keperluan yang sama. Sebagian dari mereka bekerja sebagai buruh gendong, sebagian lain bekerja membantu pedagang di pasar atau menjadi tukang tambal. Dengan demikian terbentuklah sistem seting yang menghubungkan rumah mereka dengan seting di luar rumah seperti jalan Suryotomo, jalan Malioboro, pasar Beringharjo dan pasar Sriwedani. 
Seting-seting di luar rumah tersebut sangat penting karena seting-seting itulah yang merupakan lahan kehidupan penduduk kampung yang miskin, seperti sawah sebagai lahan kehidupan petani. Seharusnya seting-seting tersebut dilestarikan karena banyak penduduk kampung yang hidupnya tergantung dari seting-seting tersebut. Dengan kata lain, rnelestarikan dan memperkuat hubungan antara rumah dengan seting-seting di pasar dan di trotoir sepanjang jalan akan mernbantu memperkuat kehidupan mereka dan kehidupan di kampung

Narnun yang terjadi adalah justru menjadi lemahnya sistem seting tadi karena ruang gerak mereka menjadi sernpit dengan hilangnya pasar Sriwedani dan berubahnya kegiatan pasar Beringharjo. Dengan rnakin maraknya pembangunan kawasan perdagangan Malioboro bagi kelompok menengah ke atas, makin sedikit pula ruang di kawasan tersebut yang dapat dimanfaatkan sebagai seting kegiatan oleh kelompok miskin di kampung-kampung sekitarnya. Kampung menjadi makin terisolasi sarnpai pada akhirnya dapat tergusur oleh lajunya pembangunan tersebut. Dengan terus berkurangnya kampung-kampung di kawasan Malioboro yang memberikan suasana tersendiri bagi kawasan ini, akan hilang pulaiah salah satu aset budaya kota Yogyakarta.

Sebuah penelitian di lakukan oleh Rapoport (1986) yang mengambil lokasi di ruang terbuka kota menggambarkan adanya kegiatan yang bersifat laten di ruang terbuka tersebut. Ruang terbuka yang fungsi manifesnya terutama adalah untuk kegiatan olahraga dan bermain ternyata juga mempunyai berbagai fungsi laten.

Ruang terbuka tersebut ternyata juga dimanfaatkan oleh para manula (kelompok manusia usia lanjut) untuk bertemu dan mengobrol tentang berbagai hal, banyak diantaranya tentang masa lalu mereka. Kesempatan untuk dapat bertemu dan mengobrol, secara psikologis memberikan kepuasan jiwa kepada mereka yang sudah mencapai masa senja ini. Fungsi laten seperti inilah yang tidak boleh diabaikan dalam setiap usaha untuk melestarikan seting-seting kegiatan. Jangan sampai seting yang memberikan wadah untuk bertemu tersebut hilang dengan datangnya pembangunan di daerah ini.

\section{Kesimpulan}

Usaha pengembangan studi kawasan dalam arkeologi banyak kesamaannya dengan studi yang sama di bidang pelestarian bangunan arsitektur. Arsitektur membahas ruang sebagai wadah kegiatan manusia. Selain membutuhkan ruang, kegiatan manusia juga mengikutsertakan berbagai benda atau peralatan bagi terselenggaranya kegiatan tersebut. Ruang, benda dan peralatan itulah yang menjadi bahan pelestarian.

Dalam setiap studi atau penelitian, peran teori atau konsep sangat menonjol karena teori atau konsep inilah yang dapat membantu menerangkan fenomena yang diteliti. Tidak kalah pentingnya adalah metoda atau cara menyelenggarakan penelitian tersebut yang akan memberi jalan dan mempermudah penyelesaian dari suatu penelitian.

Sudah menjadi kewajaran bahwa teori. konsep ataupun metoda yang berasal dari bidang ilmu lain akan dapat membantu pengembangan studi bidang iimu tertentu. Sebagai contoh, kemajuan ilmu arsitektur tidak terlepas dari sumbangan teori dan metodologi dari bidang ilmu lain termasuk bidang ilmu arkeologi. Demikian pula sebaliknya. Bidang ilmu arkeologi dapat memanfaatkan teori dan metodologi bidang ilmu lain, termasuk dari arsitektur.

Konsep sistem seting yang didalamnya terkandung aspek kegiatan manusıa dan ruang mempunyai banyak kemungkinan untuk dapat diterapkan dalam pengembangan studi arkeologi. Karena keterkaitannya dengan manusia dan ruang, konsep tersebut mempunyai prospek pemanfaatannya di bidang studi tentang pelestarian kawasan arkeologi. Bukankah studi kawasan di bidang arkeologi juga memandang kawasan sebagai ruang jelajah manusia? Bukankah arkeo-logı membicarakan artefak yang banyak kesesuaiannya dengan physical traces yang sering dibahas di bidang arsitektur?

Metoda penelusuran tanda-tanda fisik dan spasial (physical and spatial traces) yang mendasarkan pada peninggalan-peninggalan kegiatan manusia sangat bersesuaian dengan studi artefak yang banyak dilakukan di bidang arkeologi. Metoda inipun dapat dipergunakan dan disempurnakan bersama.

Dalam beberapa aspek tertentu, jarak antara penelitian di bidang arsitektur dan arkeologı menjadi sangat tipis. Dalam kondisi seperti inılah satu sama lain dapat saling memanfaatkan atau bertukar teori, konsep atau metodologi.

\section{KEPUSTAKAAN}

Bechtel, R.B. and Zeisel,J.,1987. Observation The world under a glass. In R.W. Bechtel. R. B. Marans and W. Michelson (Eds) Methods in Environmental and Beha- 
vioral Research. New York: Van Nostrand Reinhold Co.

Haryadi, 1989.Residents' strategies for coping with environmental press: Relation to house settlement systems in a Yogyakarta kampung, Indonesia (dissertation). Milwaukee: University of Wisconsin.
Rapoport, Amos, 1977. Human aspects of urban form, Oxford: Pergamon Press.

Rapoport, Amos, 1986. The use and design of open spaces in urban neighborhoods. In D. Frick (ed.) The quality of urban life. Berlin: Walter de Gruiter and Co. 